\title{
Visual evoked potentials show strong positive association with intracranial pressure in patients with cryptococcal meningitis
}

\author{
Potenciais evocados visuais mostram correlação positiva forte com a pressão \\ intracraniana em pacientes com meningite criptocócica \\ Marcelo Adriano da Cunha Silva Vieira', Maria do Amparo Salmito Cavalcanti', Dorcas Lamounier Costa², Kelsen \\ Dantas Eulálio', Otoni Cardoso do Vale ${ }^{3}$, Chrystiany Placido de Brito Vieira ${ }^{4}$, Carlos Henrique Nery Costa ${ }^{2}$
}

\begin{abstract}
Objective: To verify the relationship between intracranial pressure and flash visual evoked potentials (F-VEP) in patients with cryptococcal meningitis. Method: The sample included adults diagnosed with cryptococcal meningitis admitted at a reference hospital for infectious diseases. The patients were subjected to F-VEP tests shortly before lumbar puncture. The Pearson's linear correlation coefficient was calculated and the linear regression analysis was performed. Results: Eighteen individuals were subjected to a total of 69 lumbar punctures preceded by F-VEP tests. At the first lumbar puncture performed in each patient, N2 latency exhibited a strong positive correlation with intracranial pressure $(r=0.83 ; \mathrm{Cl}=0.60-0.94 ; p<0.0001)$. The direction of this relationship was maintained in subsequent punctures. Conclusion: The intracranial pressure measured by spinal tap manometry showed strong positive association with the N2 latency F-VEP in patients with cryptococcal meningitis.
\end{abstract}

Keywords: visual evoked potentials, intracranial pressure, cryptococcal meningitis.

\section{RESUMO}

Objetivo: Verificar a relação entre pressão intracraniana e potencial evocado visual por flash (PEV-F) em pacientes com meningite criptocócica. Método: A amostra incluiu pacientes admitidos em um hospital de referência para doenças infecciosas. Realizou-se PEV-F antes de cada punção lombar. Calculou-se o coeficiente de correlação de Pearson e a equação de regressão linear entre as variáveis latência N2 e pressão intracraniana inferida através de raquimanometria. Resultados: Dezoito pacientes foram submetidos a um total de 69 punções lombares. A latência N2 mostrou correlação positiva forte com a pressão de abertura verificada na primeira punção lombar a que cada paciente foi submetido $(r=0,83 ; I C=0,60-0,94 ; p<0,0001)$. A positividade da correlação foi mantida nas aferições subsequentes. Conclusão: Houve associação positiva forte entre a latência N2 do PEV-F e pressão intracraniana em pacientes com meningite criptocócica.

Palavras-chave: potenciais evocados visuais, pressão intracraniana, meningite criptocócica.

Intracranial hypertension $(\mathrm{ICH})$ is responsible for both early mortality and the auditory, visual, and cognitive sequelae of meningitis caused by Cryptococcus neoformans ${ }^{1,2,3}$. More than half of the patients with cryptococcal meningitis (CM) exhibit $\mathrm{ICH}^{1,3,4,5}$. Approximately 600,000 deaths associated with CM occur annually worldwide ${ }^{6}$.
Cryptococcus neoformans is the main cause of meningitis among immunocompromised individuals ${ }^{7}$. The absence of host immune response and the particularities inherent to the genesis of increased cerebrospinal fluid (CSF) pressure make clinical and radiological manifestations weak predictors of $\mathrm{ICH}$ in neurocryptococcosis ${ }^{1,2,3,4,5,8,9}$. The Infectious Diseases

${ }^{1}$ Instituto de Doenças Tropicais Natan Portella, Departamento de Neurologia, Teresina PI, Brazil;

¿Universidade Federal do Piauí, Departamento de Medicina Especializada, Teresina PI, Brazil;

3Universidade Federal do Ceará, Departamento de Medicina Clínica, Hospital Universitário Walter Cantídio, Serviço de Neurofisiologia, Fortaleza CE, Brazil; «Universidade Federal do Piauí, Departamento de Enfermagem, Teresina PI, Brazil.

Correspondence: Marcelo Adriano Cunha Silva Vieira; Departamento de Neurologia, Instituto de Doenças Tropicais Natan Portella; Rua Anfrísio Lobão, 1235 64049-280 Teresina PI, Brasil; E-mail: macsvieira@superig.com.br

Conflict of interest: There is no conflict of interest to declare.

Support: Instituto de Doenças Tropicais Natan Portella.

Received 06 August 2014; Received in final form 14 November 2014; Accepted 03 December 2014. 
Society of America recommends measuring the CSF pressure of patients with CM using a manometer for lumbar puncture at initial and follow-up assessment. ICH requires the removal of CSF using lumbar puncture on a daily basis and can even require shunts in refractory cases ${ }^{10}$.

The mechanical effects of ICH on the central visual projection pathways, together with the repercussions on brain perfusion, may slow neuronal conduction, which could be demonstrated through evoked potential testing. Although the technique to acquire visual evoked potentials using flashes of diffuse light exhibits more variability compared to techniques that apply pattern-reversal stimulation, it offers the advantage that it may be performed in the supine position and does not require strict cooperation and visual fixation, allowing this procedure to be performed even in comatose patients ${ }^{11,12}$.

A relationship has been observed between a prolongation of the latency of waves from the diffuse light flash visual evoked potential (F-VEP) test and increased intracranial pressure (ICP) in patients with hydrocephalus, traumatic brain injury or drug-related cerebral oedema ${ }^{13,14,15,16,17,18,19}$. The $\mathrm{N} 2$ component exhibits the greatest stability and is the most widely investigated parameter of the F-VEP.

To date, no study has investigated the correlation between F-VEP latencies and ICP in patients with CM. The demonstration of a correlation between ICP and the latency of the N2 wave of the F-VEP in CM may support the use of this test to infer ICP and guide the use of lumbar punctures or CSF shunts for relief. The aim of the present study was to verify the correlation between ICP and the peak latency of the N2 component of the F-VEP in patients with CM.

\section{METHOD}

The sample included adults who were hospitalized at the Natan Portella Institute of Tropical Diseases, Teresina, Brazil, between May 2011 and February 2012 with a diagnosis of CM, which was confirmed by CSF examination with India ink. The study excluded patients with macular or retinal lesions, as revealed by an ophthalmologic examination, and patients with structural impairment of the central visual pathways, as revealed by imaging techniques (computed tomography or magnetic resonance). Hepatic encephalopathy, uremia, pneumocystosis or tuberculosis as co-morbidities also led to exclusion of patients.

The ICP was inferred using lumbar puncture manometry following the recommendations of the American Academy of Neurology ${ }^{20}$. The procedures were performed and repeated only when the attending physician established their clinical indication, the patients consented and a minimum 24-hour interval had passed between measurements. The opening pressure was measured using the MVD 300 digital manometer
(Globalmed, Brazil) and the pressure around which stable oscillations occurred up to two minutes after the device was connected to the puncture needle was recorded.

The patients were subjected to F-VEP tests shortly before each lumbar puncture. Whenever the opening pressure was high ( $>20 \mathrm{~cm} \mathrm{H}_{2} \mathrm{O}$ ), the test was repeated 20 minutes after the needle was removed. The standards established by the American Clinical Neurophysiology Society ${ }^{11}$ were followed and the Neuro-MEP.micro (Neurosoft, Brazil) device was used. The electrodes were placed at the sites standardized by the International System 10-20 on Oz (active), A1 (reference), and A2 (ground).

The stimulation by flashes of diffuse light was chosen because the subjects with CSF hypertension were uncooperative to reliable fixate on a pattern stimulus. Simultaneous binocular stimulation was performed using light flashes projected through glasses with light emitting diodes on the internal surface of the goggles. The bilateral simultaneous visual stimulation aimed to minimize the magnification of any direct harmful effects of fungi on the optic nerves individually. The stimulation frequency was $1.9 \mathrm{~Hz}$ and the stimulus duration was $100 \mu \mathrm{s}$. The input impedance was $<5 \mathrm{k} \Omega$, and $1-$ to $100-\mathrm{Hz}$ filters and the average of the signals resulting from 60 stimuli were used. Three series were performed to verify the reproducibility of the curves representing the evoked potential. The identification of the peaks of the F-VEP is illustrated in Figure 1.

The parameter selected for measurement and analysis was the peak latency of the second negative deflection of the F-VEP recording. This wave is referred to as the "III" peak by American Clinical Neurophysiology Society ${ }^{11}$ or "N2" peak by International Society for Clinical Electrophysiology of Vision ${ }^{12}$. The last is the most widely used in clinical studies involving F-VEP and ICP.

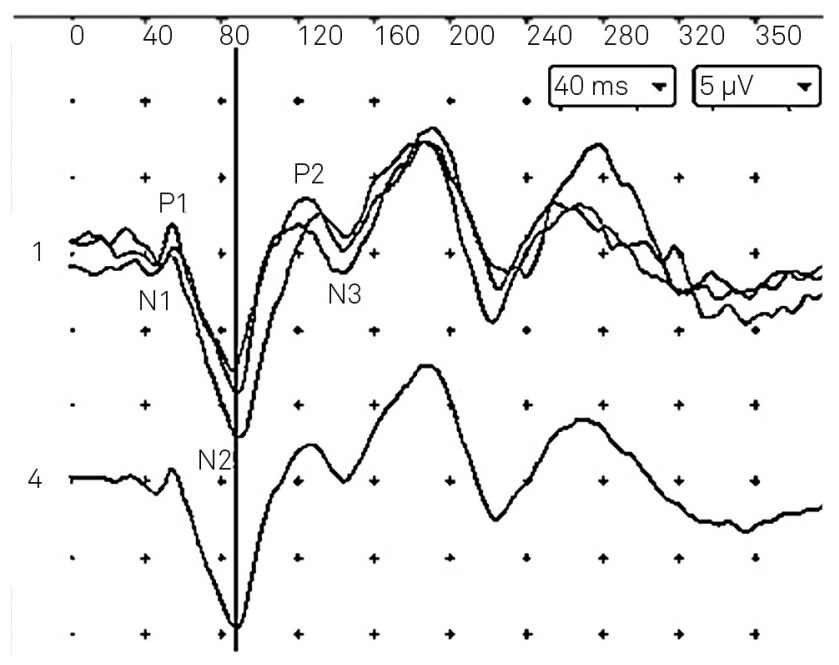

Figure 1. Flash-visual evoked potential (F-VEP) of a subject of research showing the robust $\mathrm{N} 2$ peak at $86 \mathrm{~ms}$ latency. 
The normality of distribution was investigated using the D”Agostino K-squared test. Pearson's linear correlation coefficient was calculated and linear regression analysis was performed using the variables measured at the first lumbar puncture performed after the CM diagnosis was confirmed. The linear coefficients of correlation were calculated for the average values of the opening pressure and the N2 latency assessed in consecutive lumbar punctures, together with their corresponding 95\% confidence intervals. Student's t-test for paired variables was used to investigate whether the N2 latency decreased after the ICP normalized.

The level of significance was established at $5 \%$ with a statistical power of $80 \%$ for inferential analysis. The data were processed using BioStat 2009 software (AnalysSoft Inc., Brazil). The study was approved by the Research Ethics Committee of the Federal University of Piauí and all of the patients (or their legal guardians) signed an informed consent form.

\section{RESULTS}

Eighteen patients, aged 20 to 56 years old (mean $=35.4$, standard deviation (SD) =9.4), were analyzed. Only two of the patients $(2 / 18)$ were female, and almost all of the patients $(17 / 18)$ were infected by the human immunodeficiency virus (HIV). No other cause of immunosuppression was identified in the HIV-negative patient.

Sixty-nine lumbar punctures were performed during the study, and each patient was subjected to this procedure between one and nine times. As positive India ink examination was a criterion for inclusion in the study, the measurements were performed after patients have already undergone at diagnostic lumbar puncture. Although the first lumbar puncture performed within the scope of the study exhibited a high opening pressure $\left(>20 \mathrm{~cm} \mathrm{H}_{2} \mathrm{O}\right)$ in only eight $(8 / 18)$ of the patients, most of the patients $(13 / 18)$ presented ICH at some point during evaluation, resulting in 58\% (40/69) of the measurements indicating high CSF pressure. All the sixty-nine lumbar punctures were preceded by F-VEP test. In the forty procedures in which the opening pressure was high, the F-VEP test was repeated 20 minutes after CSF drainage.

The opening pressure and F-VEP N2 latency variables exhibited a strong positive correlationat the first assessment in each patient, whit Pearson's coefficient (r) equal to 0.83 ( $\mathrm{CI}=0.60-0.94 ; \mathrm{p}<0.0001)$. Linear regression analysis showed that the equation $\mathrm{y}=1.01 \mathrm{x}-61.57$ describes ICP as a function of $\mathrm{N} 2$ latency $(\mathrm{p}<0.0001)$ (Figure 2). The magnitude of Pearson's linear coefficient of correlation (r) decreased, and the range of it confidence interval increased, when an increasing number of measurements were included in the average values for each patient (Figure 2). The N2 latency did not decrease $(t=0.79 ; p=0.21)$ when F-VEP was retested 20 minutes after the reduction of ICP by CSF drainage.

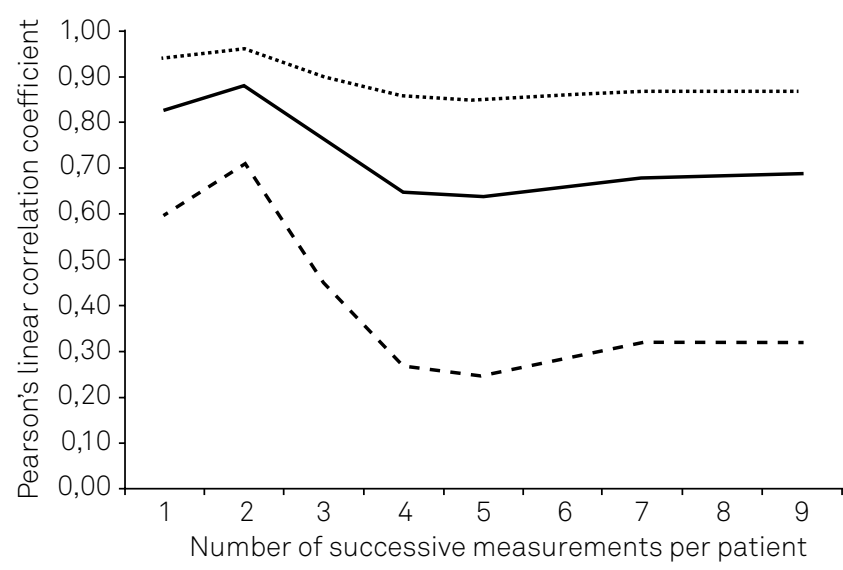

Figure 2. Pearson's linear correlation coefficient (full line) and corresponding $95 \mathrm{Cl} \%$ (dotted line) between the averages of N2 latency and opening pressure exhibited by each individual under increasing number of measurements.

\section{DISCUSSION}

The frequency of ICH detected at first assessment or during follow-up in the CM patients was similar to those reported in other case series ${ }^{1,3,4}$. The predominance of male and HIV seropositive individuals in the investigated population reflects the current epidemiological profile

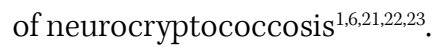

The positive correlation between ICP and F-VEP wave latency observed in studies of patients with hydrocephalus suggested this method as a mean to provide an early detection of shunt dysfunction ${ }^{13,14,16,17,18,19}$. Changes in the F-VEP latencies of patients with ICH secondary to cerebral edema have also been observed, and the use of F-VEP has been suggested to monitor ICP in head trauma victims ${ }^{14,16,17,18}$. However, F-VEP in head trauma is biased by other variables as arterial $\mathrm{pO}_{2}$, sagittal sinus venous $\mathrm{pO}_{2}$ and regional cerebral flow and is not an adequate substitute for direct ICP measures ${ }^{17,19}$.

A linear correlation between the latency of the F-VEP N2 wave and medium to high ICP values was observed under several other clinical conditions ${ }^{24}$. The present study showed similar relationship between F-VEP and ICP in patients with CM (Figure 3).

High levels of CSF pressure contribute to the appearance and irreversibility of visual, auditory, and cognitive deficits in patients with $\mathrm{CM}^{1,25,26}$. The impact of CSF hypertension on the morbidity and mortality associated with this disease supports the current recommendations to perform routine and frequent measurement of ICP using spinal tap manometry. When the opening pressure is $\geq 25 \mathrm{~cm} \mathrm{H}_{2} \mathrm{O}$, daily spinal taps and CSF drainage sufficient to reduce it to $20 \mathrm{~cm} \mathrm{H}_{2} \mathrm{O}$ or $50 \%$ of the initial value are recommended. When the opening pressure is normal on two consecutive days, the procedure should be performed once a week until the patient is discharged from the hospital or at any moment when the relapse of ICH is suspected ${ }^{10}$. 
As ICH does not systematically translate into their classical clinical manifestations or ventricular dilation on cranial tomography ${ }^{1,227}$, the time of relapse of $\mathrm{ICH}$ cannot be recognized. Accordingly, the detection of high ICP through an alternative of clinical and tomographic methods would be useful in monitoring of patients in order to indicate CSF drainage by spinal tap. While failure to address raised intracranial pressure could result in more residual neurological damage and death ${ }^{1}$, the unneeded repetition of spinal taps increases the risk of adverse events, including hemorrhage, bacterial infection, CSF hypotension, radicular involvement, epidermoid tumor, and brain herniation ${ }^{28}$. Therefore, to avoid unneeded lumbar punctures is desirable through the development of a reliable, non-invasive method to measure ICP that is easy to perform at the bedside and can identify the patients who must be subjected to spinal tap. The simple linear regression equation depicted in Figure 3 show that it is feasible the inference of ICP values from the F-VEP N2 latency.

The N2 latency did not decrease when the F-VEP test was repeated 20 minutes after reduction of the ICP. It is possible that a 20-minute interval was insufficient for the chemical and physical effects of ICH on the visual pathways to regress. In addition, some of these effects may be definitive, and other mechanisms, such as arachnoiditis, may be involved in the visual impairment of patients ${ }^{25,26,27}$. Such phenomena could explain the slight reduction in the strength of the correlation between the N2 latency and the opening pressure as a function of the subsequent spinal taps to which the patients were subjected (Figure 2). Prediction and interpretation of changes in the amplitude of the potentials after CSF drainage would be even more complex. The CSF pressure adjacent to the optic nerves tends to reduce the responses, but diffuse brain dysfunction next to it has the opposite effect ${ }^{11,19}$.

Despite the reproducibility of the curves representing the evoked potential has been verified in every measurement in this study, the intra-individual variability of N2 latency on successive tests in healthy subjects advises caution

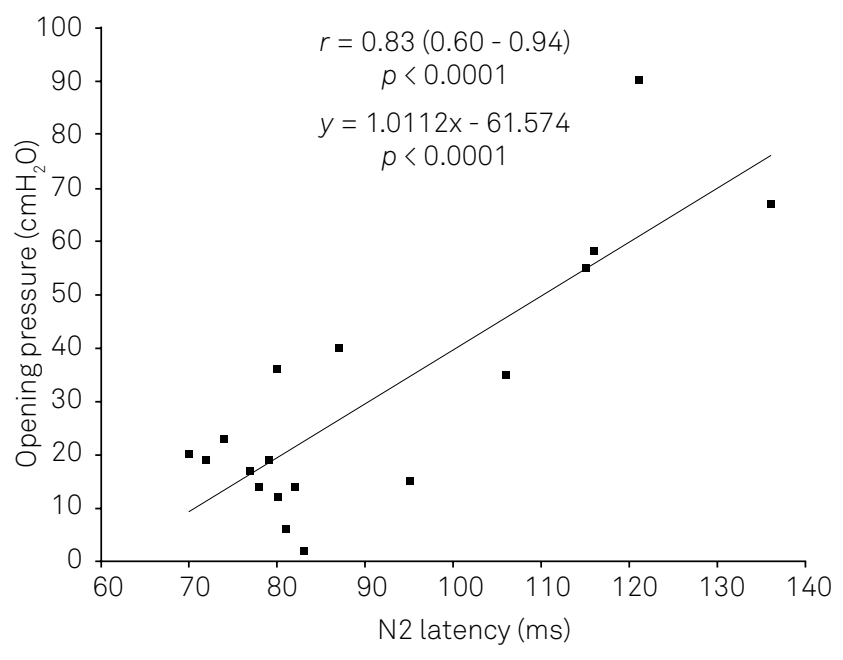

Figure 3. Diagram of dispersion of N2 latency vs. opening pressure with the corresponding Pearson's linear correlation coefficient, trend line and linear regression equation.

in interpreting F-VEP changes in clinical work ${ }^{29}$. To confirm the clinical usefulness of the F-VEP test in the management of neurocryptococcosis, studies assessing the reversibility of the visual disorders exhibited by patients are needed. Such studies must include control groups to assess the random intra-individual variability of the N2 latency during the follow-up period and partial correlation analysis to verify if arachnoiditis adjacent to the optic nerves, hypoxia, acidosis, uremia, liver failure or level of arousal constitute lurking variables. To date, the only F-VEP abnormality established by the American Academy of Clinical Neurophysiology as having definite clinical value is the absence of potentials ${ }^{11}$.

Finally, as the results of this study indicate that the N2 latency and CSF pressure exhibit a strong positive correlation, it is suggested that the F-VEP test should be explored as an indirect, non-invasive method in the diagnosis of high ICP in order to indicate the need for CSF drainage in patients with cryptococcal meningitis.

\section{References}

1. Graybill JR, Sobel J, Saag M, van Der Horst C, Powderly W, Cloud G et al. Diagnosis and management of increased intracranial pressure in patients with AIDS and cryptococcal meningitis. Clin Infect Dis. 2000;30(1):47-54. http://dx.doi.org/10.1086/313603

2. Malessa R, Krams M, Hengge U, Weiller C, Reinhardt V, Volbracht $L$ et al. Elevation of intracranial pressure in acute AIDS-related cryptococcal meningitis. Clin Investig 1994;72(12):1020-6. http://dx.doi.org/10.1007/BF00577748

3. Sun HY, Hung CC, Chang SC. Management of cryptococcal meningitis with extremely high intracranial pressure in HIV-infected patients. Clin Infect Dis. 2004;38(12):1790-2. http://dx.doi.org/10.1086/421272

4. Bicanic T, Brouwer AE, Meintjes G, Rebe K, Limmathurotsakul D, Chierakul W et al. Relationship of cerebrospinal fluid pressure, fungal burden and outcome in patients with cryptococcal meningitis undergoing serial lumbar punctures. AIDS. 2009;23(6):701-6. http://dx.doi.org/10.1097/QAD.0b013e32832605fe
5. Denning DW, Armstrong RW, Lewis BH, Stevens DA. Elevated cerebrospinal fluid pressures in patients with cryptococcal meningitis and acquired immunodeficiency syndrome. Am J Med. 1991;91(3):267-72. http://dx.doi.org/10.1016/0002-9343(91)90126-।

6. Park BJ, Wannemuehler KA, Marston BJ, Govender N, Pappas PG, Chiller TM. Estimation of the current global burden of cryptococcal meningitis among persons living with HIV/AIDS. AIDS. 2008;23(4):525. http://dx.doi.org/10.1097/QAD.0b013e328322ffac

7. Hajjeh RA, Conn LA, Stephens DS, Baughman W, Hamill R, Graviss E et al. Cryptococcosis: population-based multistate active surveillance and risk factors in human immunodeficiency virus-infected persons. J Infect Dis. 1999;179(2):449-54. http://dx.doi.org/10.1086/314606

8. Charlier C, Dromer F, Lévêque C, Chartier L, Cordoliani YS, Fontanet A et al. Cryptococcal neuroradiological lesions correlate with severity during cryptococcal meningoencephalitis in HIV-positive patients in the HAARTEra. PLoS ONE. 2008;3(4):e1950. http://dx.doi.org/10.1371/journal.pone.0001950 
9. Darzé C, Lucena R, Gomes I, Melo A. Prognostic

factors in cryptococcal meningoencephalitis.

Arq Neuropsiquiatr. 1999;57(3A):649-52.

http://dx.doi.org/10.1590/S0004-282X1999000400018

10. Perfect JR, Dismukes WE, Dromer F, Goldman DL, Graybill JR, Hamill RJ et al. Clinical practice guidelines for the management of cryptococcal disease: 2010 update by the Infectious Diseases Society of America. Clin Infect Dis. 2010;50(3):291-322. http://dx.doi. org/10.1086/649858

11. American Clinical Neurophysiology Society. Guideline 9B: guidelines on evoked potentials. J Clin Neurophysiol. 2006;23(2):138-56.

12. Odom VJ, Bach M, Brigell M, Holder GE, McCulloch DL, Tormene AP, et al. ISCEV standard for clinical visual evoked potentials (2009 update). Doc Ophthalmol. 2010;120(1):111-9. http://dx.doi.org/10.1007/s10633-009-9195-4

13. Coupland SG, Cochrane DD. Visual evoked potentials, intracranial pressure and ventricular size in hydrocephalus. Doc Ophthalmol. 1987;66(4):321-9. http://dx.doi.org/10.1007/BF00213660

14. Desch LW. Longitudinal stability of visual evoked potentials in children and adolescents with hydrocephalus. Dev Med Child Neurol. 2001;43(2):113-7. http://dx.doi.org/10.1017/S0012162201000196

15. Gumerlock MK, York D, Durkis D. Visual evoked responses as a monitor of intracranial pressure during hyperosmolar Blood-Brain Barrier Disruption. Acta Neurochir Suppl (Wien). 1994;60:132-5.

16. Sjöström A, Uvebrant P, Roos A. The light-flash-evoked response as a possible indicator of increased intracranial pressure in hydrocephalus. Childs Nerv Syst.1991;11(7):381-7. http://dx.doi.org/10.1007/BF00717400

17. Stone JL, Ghaly RF, Hughes JR. Evoked potentials in head injury and states of increased intracranial pressure. J Clin Neurophysiol. 1988;5(2):135-60. http://dx.doi.org/10.1097/00004691-198804000-00002

18. York D, Legan M, Benner S, Watts C. Further studies with a noninvasive method of intracranial pressure estimation. Neurosurgery. 1984;14(4):456-61. http://dx.doi.org/10.1227/00006123-198404000-00011

19. York DH, Pulliam MW, Rosenfeld JG, Watts C. Relationship between visual evoked potentials and intracranial pressure. J Neurosurg. 1981;55(6):909-16. http://dx.doi.org/10.3171/jns.1981.55.6.0909
20. American Academy of Neurology. Practice parameters: lumbar puncture (summary statement). Report of the Quality Standards Subcommittee of the American Academy of Neurology. Neurology. 1993;43(3 Pt 1):625-7.

21. Mirza SA, Phelan M, Rimland D, Graviss E, Hamill R, Brandt ME et al. The changing epidemiology of cryptococcosis: an update from population-based active surveillance in 2 large metropolitan areas, 1992-2000. Clin Infect Dis. 2003;36(6):789-94. http://dx.doi.org/10.1086/368091

22. Mora DJ, Colombo ERC, Ferreira-Paim K, Andrade-Silva LE, Nascentes GA, Silva-Vergara ML. Clinical, epidemiological and outcome features of patients with cryptococcosis in Uberaba, Minas Gerais, Brazil. Mycopathologia. 2012;173(5-6):321-7. http://dx.doi.org/10.1007/s11046-011-9504-9

23. Pappalardo MC, Melhem MS. Cryptococcosis: a review of the Brazilian experience for the disease. Rev Inst Med Trop S Paulo. 2003;45(6):299-305. http://dx.doi.org/10.1590/S0036-46652003000600001

24. Zhao YL, Zhou JY, Zhu GH. Clinical experience with the noninvasive ICP monitoring system. Acta Neurochir Suppl (Wien). 2005;95:351-5. http://dx.doi.org/10.1007/3-211-32318-X_72

25. Johnston SR, Corbett EL, Foster O, Ash S, Cohen J. Raised intracranial pressure and visual complications in AIDS patients with cryptococcal meningitis. J Infect. 1992;24(2):185-9. http://dx.doi.org/10.1016/0163-4453(92)92954-H

26. Lipson BK, Freeman WR, Beniz J, Goldbaum MH, Hesselink JR, Weinreb RN et al. Optic neuropathy associated with cryptococcal arachnoiditis in AIDS patients. Am J Ophthalmol. 1989;107(5):523-7. http://dx.doi.org/10.1016/0002-9394(89)90498-4

27. Tan CT. Intracranial hypertension causing visual failure in cryptococcus meningitis. J Neurol Neurosurg Psychiatry. 1988;51(7):944-6. http://dx.doi.org/10.1136/jnnp.51.7.944

28. Ellenby MS, Tegtmeyer K, Lai S, Braner DA. Lumbar puncture. N Engl J Med. 2006;355(13):e12. http://dx.doi.org/10.1056/ NEJMvcm054952

29. Andersson L, Sjölund J, Nilsson J. Flash visual evoked potentials are unreliable as markers of ICP due to high variability in normal subjects. Acta Neurochir (Wien). 2012;154(1):121-7. http://dx.doi.org/10.1007/s00701-011-1152-9 